\title{
CLIMATE CHANGE AND TRANS-BORDER MIGRATION FROM LAKE CHAD TO NIGERIA: ARE THERE POLICY RESPONSES TOWARDS A SUSTAINABLE LAKE?
}

\author{
Shaibu, M. T., Babatunde, Henry Omoyele \\ Department of Political Science and Administration, \\ Adekunle Ajasin University, Akungba-Akoko Ondo State, Nigeria \\ Ojo, Olubunmi Raphael \\ Department of Political Science University of Ibadan, \\ Oyo State, Nigeria
}

\begin{abstract}
The Herdsmen are economically significant in Africa sub-region but climate change has forced them through the Northeast geopolitical zone border with Chad into Nigeria to become a national security threat. The central aim of this study is to systematically examine whether there are extant policy responses towards revitalizing and sustaining the Lake itself. To achieve this, three questions were raised: What is the geographical and socioeconomic significance of Lake Chad? What is the nexus between the change in the Lake Climate and Herdsmen trans-border migration into Nigeria? Are there extant policy responses directed towards recharging and sustaining the Lake? This study adopted qualitative technique which relied on secondary sources. Content analytical methodology was adopted and the pull-push migration theory underpinned this study. This study found that geographical and socioeconomically, the Lake Chad is an important transnational and trans-boundary freshwater resources in the world, located between African countries sharing boundary with Chad, a source of freshwater and grazing field for Herdsmen and their herds as well as source of irrigation for agricultural activities in the region; that the shrinking of the Lake led to scarcity of freshwater and grazing field forcing the Herdsmen to migrate into Nigeria as alternative for survival; that there are existing policy responses towards addressing the challenges of climate change in the Lake Chad but there have not been any direct policy response towards revitalizing and sustaining the Lake itself. Hence, the paper recommended the need for countries at the cradle of the Lake to strengthen collaboration under the Lake Chad Basin Commission (LCBC) with International Partners to formulate policy, provide financial and technical support required to achieve the revitalization and sustainability of the Lake.
\end{abstract}

Keywords: Lake Chad, Climate Change, Trans-border Migration, Revitalization, Sustainability.

\section{INTRODUCTION}

\begin{abstract}
Climate change is happening and driven largely by human activity but something can be done to reduce its impacts and progression (Public Health Institute in Partnership with Center for Climate Change and Health, PHI/CCCH, 2016).
\end{abstract}

Climate change has pushed the Herdsmen to migrate across the border to become a national security threat. According to Oli et al. (2018), climate change are the major reasons the Herdsmen migrated southward in search for fresh water and grazing fields for their cattle or herds. Although, the Herdsmen are well known to be economically significant ethnic grouping in African sub-region. However, in recent time, the massive inflow of the Herdsmen crossing the border into Nigeria from the Republic of Chad, neighbouring African countries in search for grazing lands due to change in the climate of the Lake Chad is alarming has become a threat not only to the Farmers but to the communities where farmers are dominated as well as to the natural environment and unity of the country. Nevertheless, the change in the climate of the Lake Chad may have driven several policy responses, yet, the challenge seems to have defiled extant policy response. This issue revealed reflects and presents transnational and national challenges. One, addressing the climate change in the region and the Herdsmen-Farmers clashes. Africa Report (2017) disclosed that the Herdsmen and Farmers who are expected to contribute to food security through crop production and livestock breeding have not only clashed over grazing lands, the Herdsmen had carried out bloody attacks in several communities in Adamawa and Taraba States in Northeast zone 


\section{International Journal of Engineering Applied Sciences and Technology, 2020 \\ Vol. 4, Issue 10, ISSN No. 2455-2143, Pages 37-44 \\ Published Online February 2020 in IJEAST (http://www.ijeast.com)}

which spread to Kogi, Benue, Nasarawa, Plateau states in North Central zone as well as Zamfara State in Northwest zone as Herdsmen continue to migrate within Nigeria. The impact of the conflict as Ajala (2018) wrote:

\section{Reached an alarming level in 2017 when 1,000 people were killed in more than 50 clashes. In one night alone 73 people were killed and hundreds were injured after Herdsmen unleashed terror in two local government areas populated by farmers in Benue State.}

Worst still, Ebeku (2018) confirmed that Herdsmen have killed countless persons and burnt several villages/communities since the conflict started worsening in 2014. This scenario with environment cause, also present an environmental implication as open burning causes air pollution. Idowu (2018) has also reveals that in the history of the Nigeria's existence, Herdsmen have grazed their herds in the north and intermittently in other areas. But incremental drought with resultant desert encroachment forced them to migrate to greener grazing areas, at same time spreading conflict across the country. Hence, there is an urgent need for policy response or effort to mitigate climate change in Lake Chad. Therefore, the central aim of this study to systematically examine whether there are extant policy responses towards recharging and sustaining the Lake itself. To achieve this, three questions were raised: What is the geographical and socioeconomic significance of Lake Chad? What is the nexus between the change in the Lake Climate and Herdsmen transborder migration into Nigeria? Are there extant policy responses directed towards revitalizing and sustaining the Lake?

\section{CONCEPTUALIZING CLIMATE CHANGE AND TRANS-BORDER MIGRATION}

\section{A. Concept of Climate Change}

Climate change is an international or global concept. According to Houghton (2002) in some cases, the term climate change may refer to all environmental change or include natural variability and it is one of several symptoms of humanproduced environmental change with both global and local perspectives. A global perspective is appropriate in recognition. Climate change as the United Nations Framework Convention on Climate Change (UNFCCC, 1994) conceptualize it, is a change of climate which is attributed directly or indirectly to human activity that alters the composition of the atmosphere or environment, in addition to natural climate variability observed over comparable time periods. Agreeing to this, the Department of Climate Change and Energy Efficiency (DCCEE, 2012) conceived that: "climate is changing largely due to the observed increases in human produced greenhouse gases. Greenhouse gases absorb heat from the sun in the atmosphere and reduce the amount of heat escaping into space. This extra heat has been found to be the primary cause of observed changes in the climate system". The climate system according to Houghton (2002) consist five components in the geophysical system, the atmosphere and four others, which directly interact with the atmosphere and jointly determine the climate of the atmosphere. They are: (i) atmosphere; (ii) ocean; (iii) land surface; (iv) ice and snow surfaces (both land and ocean areas); and, (v) biosphere (both terrestrial and marine). Figure I, shows the components of the global climate system (in bold), their processes and interaction (with thin arrows) and some aspects that may change (with bold arrows). The two-way arrows in the diagram identify explicit interactions between the atmosphere and other components.

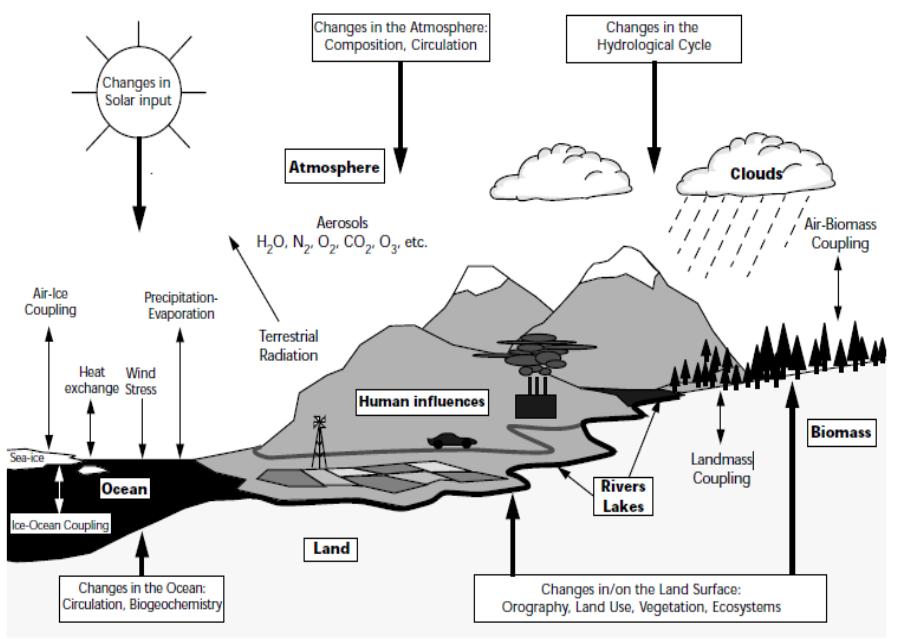

Fig.1. Schematic view of the components of the global climate system.

Source: Houghton (2002).

Notably, stakeholders in environmental discourse as Rahman (2013) succinctly points out, have characterized climate change as mainly the change in modern climate augmented by human activities. And the adverse human activities that induced climate change include: burning fossil fuel, deforestation, land degradation, loss of biological diversity, and stratospheric ozone depletion, threatens our ability to meet very basic human needs, such as adequate food, water and energy, safe shelter and a healthy environment. Interestingly, Excerpts from United States Conference of Catholic Bishops, UNCCB, 2001) agreed that:

The present generation have an obligation to respect the dignity and to pass on the natural inheritance future generation, so that their lives are protected and, if possible, made better than our own.

Interestingly, the Public Health Institute/Center for Climate Change and Health (PHI/CCCH, 2016) identified 


\section{International Journal of Engineering Applied Sciences and Technology, 2020 \\ Vol. 4, Issue 10, ISSN No. 2455-2143, Pages 37-44 \\ Published Online February 2020 in IJEAST (http://www.ijeast.com)}

climate solutions include inter-related concepts like: "mitigation", "adaptation" and/or "resilience". Mitigation: refers to measures to reduce the amount and speed of future climate change by reducing emissions of heat-trapping gases or removing carbon dioxide from the atmosphere. There are many mitigation strategies that offer feasible and costeffective ways to reduce greenhouse gas emissions. These include the use of clean and renewable energy for electricity production; walking, biking, and using low-carbon or zeroemission vehicles; reducing meat consumption; less flying; changing agricultural practices; limiting deforestation; and planting trees. Adaptation: refers to measures taken to reduce the harmful impacts of climate change through "adjustments in natural or human systems" and allow communities to thrive in the face of climate change. Cool roofs, planting trees, and air conditioning are all effective adaptation strategies to reduce the impacts of rising temperatures and more frequent heat waves. Seawalls and restoration of wetlands are both strategies to address sea level rise. Resilience: refers to the capability to anticipate, prepare for, respond to, and recover from significant threats with minimum damage to social wellbeing, economy and environment which could results to migration.

\section{B. Concept of Trans-Border Migration}

This study adopted Shaibu and Edegbo (2015) conceptualized the term migration as the movement of animal, human, goods and services within a national political territory. While, trans-border migration is the movement of animal, human being including goods and services across the national political boundaries either by land, air or water as the case may be. It is also the movement of people from one place in the world to another for the purpose of taking up permanent or semi-permanent residence, usually across a political border. The crossing of the border of a political or administrative unit for a certain minimum period of time. It includes the movement of refugees, displaced persons, uprooted people as well as economic migrants. While the occurrence of a disastrous environmental event is a significant and increasingly important cause of environmentally induced migration, more migration occurs due to less dramatic, gradual deterioration of environments. From a broader development perspective, environmental degradation appears as a proximate cause of internal and trans-border migration. The underlying causes are found in increasing population pressures on land and the patterns of resource use. Demography and political economy, in other words, are most salient causal factors. Spitz cited in Shaibu and Edegbo (2015) characterizes the impact of drought, famine and the progressive onset of food shortage associated with the gradual degradation of environments as silent drivers. No wonder, Mcauliffe and Ruhs (2018) points out that not all migration occurs in positive circumstances, that in recent years, we have seen an increase in migration and displacement occurring due to conflict, persecution, environmental degradation and change, and a profound lack of human security and opportunity. On the basis of such considerations, the algorithm uses a different color image multiplied by the weighting coefficients of different ways to solve the visual distortion, and by embedding the watermark, wavelet coefficients of many ways, enhance the robustness of the watermark.

\section{PULL-PUSH THEORETICAL UNDERPINNINGS OF TRANS-BORDER MIGRATION OF HERDSMEN}

The pull and push theory of migration is applicable to this study as it help to understand motive or factors in population or demographic movements. According to Velazquez (2000); Rank (2019), the pull and push theory of migration was first coined by Ravenstein of England in the 19th century. As Udeoji and Shaibu (2019) explained it, push factor are forces that draw people away from a place; example include food shortage, crime, war, flood lack of services. While pull factors are forces that draw people to immigrate to a place. For example political stability, favourable climate and safety. Idowu (2018) theorizes that, the factors in pull and push theory of migration could be environmental, political, economic and cultural, or any combination thereof as well as demographic and social. It follows that the migration of the Herdsman out of the Lake Chad Basin to some states in Northeastern Nigeria and subsequent spreading to other states in North Central for grazing lands gives credence to the environmental factor in the pull and push theory of migration. Basically, the environmental factor as Idowu (2018) further explained was the emerging shrinking of Lake Chad pushed the Herdsmen out of the Lake Chad to look elsewhere for grazing lands/fields favourable for them and their herds. This continue to pull Herdsmen Southward from the Northeastern Nigeria. He added that, the consequence of the change in the climate of Lake Chad displaced about 10.5 million people. Acknowledging that the Herdsmen habitually migrate annually from north to south with their cattle in search for grazing fields/lands seasonally. But with climate change, the movement pattern was markedly altered. The combination of factors including: expansive of desertification, drought and unchecked deforestation in Northern Nigeria, pushed Herdsmen from Northeastern Nigeria, the region closest to Lake Chad and further seeking green pastures southward of the country. As the resultant migration has intensified, so too has violent clashes over grazing lands between local Farmers and Herdsmen, whom the former accuses of wanton destruction of their farm crops and forceful appropriation of their lands.

\section{RESEARCH METHODOLOGY}




\section{International Journal of Engineering Applied Sciences and Technology, 2020 \\ Vol. 4, Issue 10, ISSN No. 2455-2143, Pages 37-44 \\ Published Online February 2020 in IJEAST (http://www.ijeast.com)}

This study adopted qualitative technique which depends on secondary sources. Relevant contents extracted from reputable transnational and national policy documentations after a careful examination to provide answers to the questions earlier raised. The materials generated are largely from print media such as internet, comprising of journals articles, global and African report on climate change migration as well as documentations on climate change mitigation and adaptation in Lake Chad and Nigeria. The findings are thematically presented and content analytical method was used. Authors were acknowledged appropriately.

\section{FINDINGS AND DISCUSSION}

\section{A. The Geographical and Socioeconomic Significance of Lake Chad.}

It was found that the Lake is geographically located within the Sudano-Sahelian region, at the coordinates $12^{\circ} 20$ $\mathrm{N}-14^{\circ} 20 \mathrm{~N}$ and $3^{\circ} 00 \mathrm{E}-15^{\circ} 20 \mathrm{E}$. About $20 \%$ of the total area of the Lake Chad Basin, or $427500 \mathrm{~km}^{2}$ called the Conventional Basin (42\% in Chad, $28 \%$ in Niger, $21 \%$ in Nigeria and $9 \%$ in Cameroon), which is under the mandate of the Lake Chad Basin Commission. This commission was created in 1964 by the four member states with the objective of ensuring the most rational use of water, land and other natural resources and to coordinate regional development (Food and Agriculture Organization, FAO, 1997). Lake is one of the most important transnational and trans-boundary freshwater resources in the world, it occupies $8 \%$ of African continental land area. The Lake expanse extends to eight African nations involving Cameroon, Algeria, Chad, Central African Republic, Niger, Libya, Sudan and Nigeria (Onamuti et al, 2017).

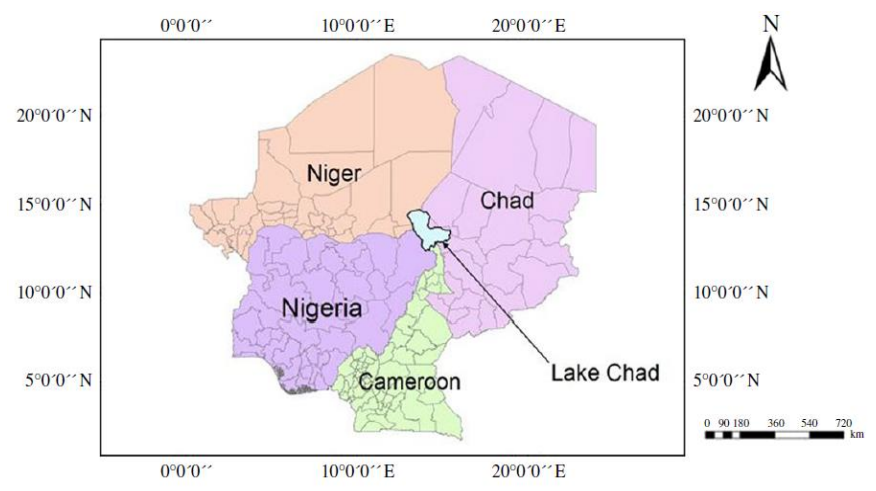

Fig. 2. Location of the Lake in Between Four Bordered African Neighbours.

Source: Onamuti, Okogbue and Orimoloye (2017).

Socioeconomically, information from Ross (2018) reveals that the Lake constitutes a source of water to millions of people in West Africa. According to Okpara et al (2015) the Chari-Logone River (in the Central African Republic), the
Komadugu-Yobe River (in Nigeria) and the Yedsaram/Ngadda River (in Cameroon) constitutes the three main drainage systems that supply its water. GIZ (2015) identified that the multi-ethnic population of the Lake Chad Basin rose from some 17 million people in 2005 to the current total of around 38 million. The dominant groups are the Hausa, Fulani and Kanuri groups along the western shores of the Lake (Nigeria), the Mousgoun in Yaere (Cameroon) and the Sara and Kotoko in the Chari Delta (Chad). This population is predominantly rural, thriving on climatesensitive agriculture-related activities. Before the current state, the Lake waters supported massive agricultural production: fishing, animal husbandry and growing of food crops (such as cotton, groundnut, cassava, millet, onions, rice, maize and sorghum) - which in turn supported the economy of the region and both the Herders and their herds depended on this resources for survival.

For instance, evidence from Africa Report (2017) confirmed that more than 90 per cent of Fulani across several West and Central African countries own approximately 90 per cent of the national herd, estimated at 19.5 million cattle, about 975,000 donkeys, 28,000 camels, 72.5 million goats and 41.3 million sheep. Livestock represents between 20 and 30 per cent of total agricultural production and about 6 to 8 per cent of overall Gross Domestic Production (GDP). It was uncovered by Okpara et al (2015) that for the entire 20th century, the Lake was at its highest level between 1960 and 1963 human population dynamics including the Herdsmen around Lake Chad are driven by a southward migration trend following the collapse of the Lake in the 1970s and 1980s. This trend has changed the Lake's demographic structure and created new production and development concerns.

\section{B. The Nexus between Change in the Lake Climate and Herdsmen Trans-Border Migration.}

It was revealed by Idowu (2018) that the $5.62 \%$ $(1805.942 \mathrm{~km} 2)$ total decrease in the area extent of the shrunk Lake reduced to sand dune and turbid water from 1987 to 2005 could be ascribed to increasing successional colonization of the area by wetland plant species. Other contributors to Lake Chad shrinkage include Lake Water discharge to groundwater, and dam construction on the tributaries. For instance, $45 \%$ water inflow reduction to the Lake has been attributed to Tiga and Challawa dams constructed on Komadugu Yobe River in 1974 and 1992 respectively. Approximately 42\%, 60\% and 83\% reduction of Lake have been linked to reduction of inflow to the Lake from Chari River, Kumadugu Yobe and El Beid, respectively, over the years due to heavy used of these rivers for irrigational farming without plan to recharge them. Socioeconomic outcomes of the Lake contraction could be evidenced as reduced crop yield and production; food and feed insecurity; biodiversity decline and loss; loss of fishing ground; increasing unemployment; 
high crime rate, stealing of cow, hunger and diseases leading to increasing relocation and migration.

Deutsche Gesellschaft fur Internationale Zusammenarbeit (GIZ, 2015) citing the Intergovernmental Panel on Climate Change (IPCC) and the United Nations Environment Programme agreed that the surface area of Lake Chad shrunk from 25,000 square kilometres in the 1960 s to 4,800 square kilometres in 2014 and linked half of this reduction to the effects of climate change and the other half is caused by increased use Lake Chad for irrigation and to meet the needs of a constantly growing population, especially in Nigeria, Cameroon and Chad.

Obaji (2018) reveals that as the lake shrank, large numbers of herders had to search for alternative pastures and sources of water for their cattle, leading to trans-border migration and encroachment on settlements as well as farmlands in Nigeria. These encroachments have brought on disputes over crop damage and cattle theft that mostly turn violent in Nigeria. It is no wonder, Oli et al (2018) linked the Herdsmen migration Southward in search of fresh water and grass for their cattle to climate change given credence to pushpull theory of migration. This shows that environmental factor has the tendency to force demographic movement and cause conflict in the host destination due to competition as well as claims over resources which largely explains the Herdsmen migration scenario.

\section{Are there Extant Policy Responses towards Recharging and Sustaining the Lake?}

As at the time of carrying out this study, there are no policy response found to be directed towards revitalizing and sustaining the Lake itself. But existing policy responses found, were only to address challenges melted on the people by the change in Lake Chad climate as showed in Table 1.

Table - 1 Evidences of Policy Responses.

\begin{tabular}{|c|c|c|c|}
\hline $\begin{array}{l}\text { Policy } \\
\text { Response }\end{array}$ & Year & Objectives & $\begin{array}{l}\text { Partners/ } \\
\text { Sponsors }\end{array}$ \\
\hline $\begin{array}{l}\text { The Lake } \\
\text { Chad } \\
\text { Developme } \\
\text { nt and } \\
\text { Climate } \\
\text { Resilience } \\
\text { Action Plan } \\
\text { (LCDAP) } \\
\text { approved } \\
\text { by the } \\
\text { Basin's } \\
\text { Council of } \\
\text { Ministers. }\end{array}$ & 2015 & $\begin{array}{l}\text { a new action plan } \\
\text { aims to empower } \\
\text { Lake Chad } \\
\text { communities to adapt } \\
\text { to the urgent } \\
\text { development } \\
\text { challenges } \\
\text { exacerbated by } \\
\text { climate change, and } \\
\text { to consolidate Lake } \\
\text { Chad's contribution } \\
\text { to regional food } \\
\text { security. The } \\
\text { objectives was to turn } \\
\text { Lake Chad into a } \\
\text { pole of regional rural } \\
\text { development by }\end{array}$ & $\begin{array}{l}\text { developed } \\
\text { by the Lake } \\
\text { Chad Basin } \\
\text { Commission } \\
\text { (LCBC) and } \\
\text { its six } \\
\text { member } \\
\text { states; } \\
\text { Cameroon, } \\
\text { Central } \\
\text { African } \\
\text { Republic, } \\
\text { Chad, Libya, } \\
\text { Niger and } \\
\text { Nigeria with } \\
\text { support from } \\
\text { the World }\end{array}$ \\
\hline
\end{tabular}

\begin{tabular}{|c|c|c|c|}
\hline & & $\begin{array}{l}\text { sustainably } \\
\text { improving: } \\
\text { - the living } \\
\text { conditions of the } \\
\text { populations settled } \\
\text { on the Lake's } \\
\text { banks and Islands, } \\
\text { and } \\
\text { - the resilience of } \\
\text { the Lake's socio- } \\
\text { ecosystem, which } \\
\text { faces strong } \\
\text { demographic } \\
\text { growth, high } \\
\text { hydrological } \\
\text { variability, and } \\
\text { climate } \\
\text { uncertainty. }\end{array}$ & $\begin{array}{l}\text { Bank and } \\
\text { French } \\
\text { Developmen } \\
\text { t Agency. } \\
\text { The plan is } \\
\text { part of the } \\
\text { World } \\
\text { Bank's } \$ 16 \\
\text { billion } \\
\text { Africa } \\
\text { Climate } \\
\text { Business } \\
\text { Plan, which } \\
\text { was recently } \\
\text { presented at } \\
\text { the COP21 } \\
\text { conference } \\
\text { in Paris. }\end{array}$ \\
\hline $\begin{array}{l}\text { Adapting to } \\
\text { climate } \\
\text { change in } \\
\text { the Lake } \\
\text { Chad } \\
\text { Basin. }\end{array}$ & $\begin{array}{l}2013 \text { to } \\
2018\end{array}$ & $\begin{array}{l}\text { to implement } \\
\text { effective measures } \\
\text { for adapting } \\
\text { agricultural practices } \\
\text { in the Lake Chad } \\
\text { Basin to climate } \\
\text { change. } \\
\text { a platform for } \\
\text { regional knowledge } \\
\text { transfer facilitates the } \\
\text { exchange of } \\
\text { information and data } \\
\text { on climate change to } \\
\text { raise awareness on } \\
\text { climate change } \\
\text { among local producer } \\
\text { groups and } \\
\text { associations. } \\
\text { the project supports } \\
\text { the Lake Chad Basin } \\
\text { Commission through } \\
\text { capacity development } \\
\text { and in particular the } \\
\text { provision of expertise } \\
\text { on climate change } \\
\text { and strategies and } \\
\text { measures for } \\
\text { adapting traditional } \\
\text { and modern } \\
\text { agricultural practices } \\
\text { accordingly. }\end{array}$ & $\begin{array}{l}\text { lead } \\
\text { executing } \\
\text { agency: } \\
\text { Lake Chad } \\
\text { Basin } \\
\text { Commission } \\
\text { (LCBC) set } \\
\text { up in 1964. }\end{array}$ \\
\hline $\begin{array}{l}\text { Food and } \\
\text { Agricultura } \\
1 \\
\text { Organizatio } \\
\text { n (FAO) } \\
\text { Response } \\
\text { strategy. A } \\
\text { twin-track }\end{array}$ & $\begin{array}{l}2017- \\
2019\end{array}$ & $\begin{array}{l}\text { stressed the } \\
\text { importance of } \\
\text { providing lifesaving } \\
\text { assistance to those in } \\
\text { need, while also } \\
\text { addressing the root } \\
\text { causes of the crisis. }\end{array}$ & $\begin{array}{l}\text { participants } \\
\text { at the May } \\
\text { 2016 Lake } \\
\text { Chad Basin } \\
\text { Second } \\
\text { Regional } \\
\text { Security } \\
\text { Summit in }\end{array}$ \\
\hline
\end{tabular}




\section{International Journal of Engineering Applied Sciences and Technology, 2020 \\ Vol. 4, Issue 10, ISSN No. 2455-2143, Pages 37-44 \\ Published Online February 2020 in IJEAST (http://www.ijeast.com)}

\begin{tabular}{|c|c|c|c|}
\hline $\begin{array}{l}\text { approach to } \\
\text { the Lake } \\
\text { Chad Basin } \\
\text { crisis. }\end{array}$ & & $\begin{array}{l}\text { prioritize sustainable } \\
\text { and equitable access } \\
\text { to resources and } \\
\text { services, as well as } \\
\text { the sustainable } \\
\text { growth of livelihood } \\
\text { opportunities. } \\
\text { strengthening } \\
\text { resilience by linking } \\
\text { emergency } \\
\text { interventions to } \\
\text { lasting recovery is } \\
\text { essential. } \\
\text { rapidly address the } \\
\text { food insecurity } \\
\text { situation, while also } \\
\text { tackling the drivers } \\
\text { of conflict and } \\
\text { instability in the } \\
\text { region. } \\
\text { providing seed and } \\
\text { agricultural inputs } \\
\text { before the planting } \\
\text { season (May-July) is } \\
\text { essential to ensure } \\
\text { staple crop harvests, } \\
\text { which will have the } \\
\text { greatest impact on } \\
\text { food security in the } \\
\text { region. }\end{array}$ & $\begin{array}{l}\text { Abuja, as } \\
\text { well as } \\
\text { Stephen } \\
\text { O'Brien, the } \\
\text { Under- } \\
\text { Secretary } \\
\text { General for } \\
\text { Humanitaria } \\
\text { n Affairs and } \\
\text { Emergency } \\
\text { Relief } \\
\text { Coordinator } \\
\text { in his } \\
\text { statement to } \\
\text { the UN } \\
\text { Security } \\
\text { Council on } \\
\text { 12 January } \\
\text { 2017. }\end{array}$ \\
\hline $\begin{array}{l}\text { FAO, } \\
\text { Sustainable } \\
\text { natural } \\
\text { resource } \\
\text { manageme } \\
\text { nt. }\end{array}$ & $\begin{array}{l}\text { Not } \\
\text { Available }\end{array}$ & $\begin{array}{l}\text { is the adoption of } \\
\text { land and water use } \\
\text { systems that, through } \\
\text { appropriate } \\
\text { management } \\
\text { practices, enable } \\
\text { users to maximize the } \\
\text { economic and social } \\
\text { benefits of those } \\
\text { resources while } \\
\text { maintaining or } \\
\text { enhancing their } \\
\text { ecological support } \\
\text { functions. } \\
\text { ensure that the causes } \\
\text { of the degradation } \\
\text { and corrective } \\
\text { measures are } \\
\text { properly identified, } \\
\text { and that the policy } \\
\text { and regulatory } \\
\text { environment enables } \\
\text { the adoption of the } \\
\text { most appropriate } \\
\text { management } \\
\text { measures. }\end{array}$ & $\begin{array}{l}\text { requires } \\
\text { collaboration } \\
\text { and } \\
\text { partnership } \\
\text { at all levels } \\
\text { - land and } \\
\text { water users, } \\
\text { technical } \\
\text { experts and } \\
\text { policy- } \\
\text { makers. }\end{array}$ \\
\hline
\end{tabular}

\begin{tabular}{|l|l|l|l|}
\hline & & & \\
\hline $\begin{array}{l}\text { FAO, } \\
\text { Preserving } \\
\text { the } \\
\text { environmen } \\
\text { tal capital } \\
\text { of the } \\
\text { Lake. }\end{array}$ & $\begin{array}{l}\text { Not } \\
\text { Available }\end{array}$ & $\begin{array}{l}\text { local actions taken to } \\
\text { preserve the current } \\
\text { and future } \\
\text { environmental capital } \\
\text { of resource shared } \\
\text { between the four } \\
\text { countries. }\end{array}$ & $\begin{array}{l}\text { FAO will } \\
\text { ensure its } \\
\text { activities } \\
\text { take into } \\
\text { account the } \\
\text { sustainabilit } \\
\text { y of the } \\
\text { livelihoods } \\
\text { related to the } \\
\text { exploitation } \\
\text { of the } \\
\text { natural } \\
\text { population on good } \\
\text { practices and } \\
\text { environmental } \\
\text { sensitization is } \\
\text { essential. }\end{array}$ \\
\hline $\begin{array}{l}\text { Sources: } \\
\text { Reconstruction }\end{array}$ \\
Association (IBRD/IDA 2016); FAO (2017); GIZ (2015).
\end{tabular}

\section{CONCLUSION}

The Herdsmen are economically significant in Africa subregion but climate change has forced them through the Northeast geopolitical zone border with Chad into Nigeria to become a threat to humanity across community settlements in the country. The central aim of this study was to systematically examine whether there are extant policy responses towards revitalizing and sustaining the Lake itself. Three questions raised are: What is the geographical and socioeconomic significance of Lake Chad? What is the nexus between the change in the Lake Climate and Herdsmen transborder migration into Nigeria? Are there extant policy responses directed towards revitalizing and sustaining the Lake? Geographical and socioeconomically study findings reveals that the Lake Chad is an important transnational and trans-boundary freshwater resources in the world, located between African countries sharing boundary with Chad, a source of freshwater and grazing field for Herdsmen and their herds as well as irrigation for agricultural activities in the region. However, the shrinking of the Lake has led to drought, scarcity of freshwater and grazing field forcing the Herdsmen to migrate into Nigeria in search for same as alternative to survival. It was also discovered that there are existing policy responses towards addressing the challenges of climate change in the Lake Chad but there have not been any direct policy response towards revitalizing and sustaining the Lake itself. Hence, except the shrunk Lake which is the root cause is revitalized, the challenge of climate change in Lake Chad and Herdsmen will not return to their base in Lake Chad, they will remain in Nigeria with their herds and crisis with the Famers will thrive. To address the root cause of the climate change and to get the Herdsmen return back to the Lake Chad Basin (LCB) where they have migrated from, the following crucial steps are recommended:

i. There is need for countries at the cradle of Lake Chad Basin to strengthen collaboration with International Partners World Bank (WB), United Nations (UN), French Development Agency (FDA) through the Lake Chad 


\section{International Journal of Engineering Applied Sciences and Technology, 2020 \\ Vol. 4, Issue 10, ISSN No. 2455-2143, Pages 37-44 \\ Published Online February 2020 in IJEAST (http://www.ijeast.com)}

Basin Commission (LCBC) to formulate policy towards revitalizing and sustaining the Lake itself. This collaboration should investigate and identify how possible it will be to recharge or revitalize the Lake by tapping from continental waters at the Gulf of Guinea or Atlantic oceans in the region.

ii. The Lake Chad Basin Commission should liaise with the International Partners to provide financial and technical supports that is require to achieve the revitalization and sustainability of the Lake.

iii. Extant policies could also be reviewed and expanded by stakeholders to cover revitalization and sustainability (RC) of the Lake.

\section{REFERENCES}

[1] Africa Report, (2017). Herders against Farmers: Nigeria's expanding Deadly Conflict. International Crisis Group (ICG), https://www.ecoi.net/en /file/local/1410340/1226_1505986246_252-nigeriasspreading-herder-farmer-conflict, (pp.1-38) (accessed May 14, 2019).

[2] Ajala, O. (2018). "Why Clashes are on the rise between Farmers and Herdsmen in the Sahel". The Conversation Africa, Inc. https://reliefweb.int/report/nigeria/whyclashes-are-rise-between-farmers-and-herdsmen-sahel (pp.1-9) (accessed May 15, 2019).

[3] DCCEE, (2012). Department of Climate Change and Energy Efficiency: Climate Change in a nutshell. Australian Government, Canberra, 2012, www.googlesearch.com (pp.1-4) (accessed May 15, 2019).

[4] Denis, M. G. et al (2016). The Lake Chad Development and Climate Resilience Action Plan. Washington, D.C.: World Bank Group. http://documents.worldbank.org/ curated/en/365391467995401917/Summary, (pp. 1-15) (accessed June 29, 2019).

[5] Ebeku, K.S.A. (2018). Legal Implications of Recurrent Mass Killings in Nigeria by Fulani Herdsmen. Journal of Law and Criminal Justice, 6(2), (pp. 44-61), DOI: 10.15640/jlcj.v6n2a4,https://doi.org/10.15640/jlcj.v6n2 a4 (accessed May 14, 2019).

[6] FAO (2017). Lake Chad Basin Crisis Response strategy (2017-2019), http://webcache.googleusercontent.com/ search?q=cache:2s2HXxfBeKQJ:www.fao.org/3/ai7078e.pdf $+\& \mathrm{~cd}=7 \& \mathrm{hl}=\mathrm{en} \& \mathrm{ct}=\mathrm{clnk} \& \mathrm{gl}=\mathrm{ng} \& \mathrm{client}=$ fir efox-b-d (pp. 1-18) (accessed June 13, 2019).

[7] FAO, (1997). "Irrigation Potential in Africa: A Basin Approach," FAO Land and Water Bulletin 4, ISBN: 92-
5-103966-6, http://www.fao.org/3/W4347E/w4347e0j. htm (pp. 1-5) (accessed June, 12, 2019).

[8] GIZ, (2015). Adapting to climate change in the Lake Chad Basin. Lead executing agency: Lake Chad Basin Commission ( $L C B C$ ), https://www.giz.de/en/worldwide /24845.html (pp. 1-5) (accessed June 13, 2019).

[9] Houghton, D. D. (2002). Introduction to Climate Change. Lecture Notes for Meteorologists. Geneva: Secretariat of the World Meteorological Organization, WMO-No. 926, 2002, (pp.1-143) (accessed May 17, 2019).

[10] IBRD/IDA, (2016). Investing in Resilience and Development in Lake Chad. The Word Bank, http://www.worldbank.org/en/news/feature/2016/02/11/ investing-in-resilience-and-development-in-lake-chad (pp. 1-5) (accessed May 29, 2019).

[11] Idowu, O. (2018). How Climate Change Influences Herdsmen in Nigeria. Nigeria News Brief and Action Alert, https://www.climatescorecard.org/2018/05/howclimate-change-influences-herdsmen-in-nigeria/ (pp. 111) (accessed May 16, 2019).

[12] Mcauliffe, M. and Ruhs, M. (2018)."World Migration Report 2018". International Organization of Migration: Geneva,https://publications.iom.int/system/files/pdf/wmr _2018_en_chapter1.pdf. (pp.1-15) (accessed May 19, 2019).

[13] Obaji, P. (2018). Recharging Lake Chad Key to Ending the Conflict between Nigeria's Farmers and Herders. International Peace Institute (IPI). https://reliefweb. int/report/nigeria/recharging-lake-chad-key-endingconflict-between-nigeria-s-farmers-and-herders (pp.1-6) (accessed February 5, 2020).

[14] Oli, N.P. et al (2018). Prevalence of Herdsmen and Farmers Conflict in Nigeria. International Journal of Innovative Studies in Sociology and Humanities (IJISSH), 3 (1), (pp.30-39) (accessed June 1, 2019).

[15] Okpara, U.T. et al (2015). Conflicts about water in Lake Chad: Are environmental, vulnerability and security issues linked? Progress in Development Studies, 15(4). (pp. 1-29). https:// dx.doi.org/101177/ 1464993415592738, (accessed June 12, 2019).

[16] Onamuti, O. Y. et al (2017). Remote Sensing Appraisal of Lake Chad Shrinkage Connotes Severe Impacts on Green Economics and Socio-economics of the Catchment Area. Royal Society Open Science, 4(11), 
(pp.1-12),http://dx.doi.org/10.1098/bos171120 (accessed May 20, 2019).

[17] PHI/CCCH, (2016). "Climate Change 101: Climate Science Basics" Public Health Institute in Partnership with Center for Climate Change and Health, climatehealthconnect.org/wp-content/uploads/2016/09/ Climate101.pdf (pp.1-10) (accessed May 16, 2019).

[18] Rahman, M. I. (2013). Climate Change: A Theoretical Review. Convention. Interdisciplinary Description of Complex Systems 11(1), DOI:10.7906/indecs.11.1.1, (pp1-13), http://unfccc.int/essential_background/conven tion/background/items/2536.php (accessed May 14, 2019).

[19] Rank, J. (2019). "Theories of Migration" https://family.jrank.org/pages/1170/Migration-Theories -Migration.html (pp. 1-7) (accessed May 18, 2019).

[20] Ross, W. (2018). Lake Chad: Can the vanishing lake be saved? https://www.bbc.com/news/world-africa43500314 (pp. 1-12) (accessed May 18, 2019).

[21] Shaibu, M. T. and Edegbo, S. (2015). International Migration". Abuja: National Open University of Nigeria press, (pp.1-127).

[22] UNCCB, (2001). Global Climate Change: A Plea for Dialogue, Prudence, and the Common Good. Washington, DC: United States Conference of Catholic Bishops. 2001, http://old.usccb.org/sdwp/international/ globalclimate.shtml (pp.1-32) (accessed May 17, 2019).

[23] Udeoji, E. A. and Shaibu, M. T. (2019). International Relations of Migration: Issues and Challenges. Nigeria: Best Solution Polytechnic press, (pp.1-321).

[24] UNFCCC, (1994). United Nations Framework Convention on Climate Change: Fact sheet: Climate Change science - The status of Climate Change science today, https://unfccc.int/files/press/backgrounders/appli cation/pdf/press_factsh_science.pdf (pp.1-7) (accessed May 15, 2019).

[25] UNCCS, (2018). Global Climate Action 2018 Examples of Good Practice, https://unfccc.int/sites/ default/files/resource/GCA_TD_GoodPractices_2018.p df (pp.1-16) (accessed June 14, 2019).

[26] Velazquez, F. C. (2000). "Approaches to the study of International Migration: A Review". Estudios Fronterizos, 1(1), (pp. 1-32), https://dialnet.unirioja.es/ descarga/articulo/5196039.pdf (accessed May 18, 2019). 